\title{
The Equity-Equality Conflict—Dilemmas in the Management of Reward Systems
}

\author{
Steen Scheuer ${ }^{1}$ \\ ${ }^{1}$ Department of Leadership and Corporate Strategy, University of Southern Denmark, Denmark \\ Correspondence: Steen Scheuer, Department of Leadership and Corporate Strategy, University of Southern \\ Denmark, Denmark. E-mail: steen.scheuer@sdu.dk
}

Received: March 19, 2013

Accepted: April 10, 2013 Online Published: July 3, 2013

doi:10.5539/jms.v3n3p158

URL: http://dx.doi.org/10.5539/jms.v3n3p158

\begin{abstract}
This article investigatesthe factors that determine workplace actors' appeal to social norms of fairness in some situations and what 'fairness' is perceived as consisting of. When is a pay level considered as relativity fair, and when is it not? When are contingent pay systems (i.e. pay-for-performance systems) perceived as fair and when are they not? When can differences in contribution (equity) overrule the social norm of equality? Which contingent reward structure should be applied for teamwork members, if any? Which structure to motivate employees to a continuous search for smarter working procedures and solutions? These are central concerns of motivation theory, where rational choice decisions are counterbalanced by endowment effectsor other fairness concerns. Management is placed in a dilemma between what is, e.g., an economically rational structure of incentives, on the one hand, and what is considered as equitable by employees, on the other. Since equality in reward counts for more among employees, while equity in contribution counts more for employers, this is an inherent dilemma, constantly having to be negotiated and solved, but never reaching any 'final solution' in any company. On the basis of this dilemma, implications for management are spelt out, and recommendations for the utilization of and limitations for pay variance among peers are given.
\end{abstract}

Keywords: management, motivation, social norms, endowment effect, contingent reward systems, employment relationship

\section{Motivation and Fairness}

The general theme of this article is to investigate into the causal relationship between willingness to contribute in the workplace and the effect of employees' social norms. The employment relationship is an exchange relationship, but 'once the wage has been determined, this sets the stage for conflicts over work effort' (Hechter 1987: 127). Not only effort is in focus here, however, but contribution more generally, encompassing besides effort also commitment, persistence, willingness to change, to submit novel ideas etc. These aspects are highly sensitive to fairness issues, issues that impinge on the question of variance of social norms in employment situations and among different kinds of employees, including institutional factors that support or minimize the effectiveness of particular normative statement in the workplace condition. Social norms of fairness and of normality are important forces that influence our conduct in the employment relationship. Beside incentives, the conception of what is normal and what is fair strongly impinge on our conceptions and thus on our agency. The issue of social norms of fairness has been widely discussed in sociology, economics and psychology, and the impact of social norms on economic micro-decisions have by now been established (Boudon 2001, Elster 1989a, 2007, 2009, Joas 2000, Kahneman 2011, Kahneman et al. 1986a, 1986b, 1990), including the importance of institutional and legal factors in forming employees' conceptions of fairness (cf. Fehr et al. 2009). However, 'fairness concerns' is a quite general term, since fairness may relate to equity as well as equality norms and values, and thus the point of reference for evaluating 'fairness' may differ quite profoundly. Equity fairness refers to a balance between contribution and reward (Elster 1989a), and thus the employment relationship between company and employee, while equality fairness brings the reward of the individual employee in relation to that of his/her colleagues. Since both the effort and the value of the contribution are usually less visible than reward differentials, it turns out to be difficult to bring equity into play among colleagues. Who should do it?

Also, in the employment context, one basic problem related to social norms is the fact that while the contractual salary payment is contractually binding, the desired level of contribution is not, and it is only enforceable in the 
general sense that an employee may be warned, demoted or fired as a result of poor performance (in the employer's eyes). This is the nature of the open-ended psychological contract (Marsden 2004a, Rousseau 1995). This contract puts social norms of fairness centre stage. The impact of fairness in workplace daily interactions may appear slight, but the impact of unfairness is substantial, and perceived level of pay fairness (including perceptions of pay relativities) certainly impinge on contribution (Abell 1995, Fehr et al. 2009: 366, 369). Fairness is enforced, but sometimes this comes to the detriment of all participants' outcomes (Axelrod 1984). This is important, because effort, commitment, persistence, change willingness - in other words, motivation are important indicators of individual and organizational performance. In fact, the proponents of what is sometimes labelled 'New Pay' (i.e. more flexible pay systems, such as contingent pay, performance-based pay etc.) to a quite substantial effect seem to neglect fairness effects when they argue an ever-increasing utilization of individualized performance-related payment systems (PRP), cf. e.g. Lawler $(1990,2000)$ and Schuster and Zingheim (1992).

Therefore, since the employment relationship may be seen as an iterated Prisoner's Dilemma between the employer and the employee (Axelrod 1984) or as a continuous renegotiation of the effort bargain (Marsden 2004b), for management it is important to understand the nature and substance of the particular social norms present and to understand which factors may facilitate or hinder changing these norms. This is particularly pertinent for companies and organizations undergoing constant change impetuses, as e.g. with the increasing use of high-involvement management, where increases in delegation, empowerment and involvement may be seen sometimes to have ambiguous consequences, if more demanding jobs are not followed by social supportive supervision, by rewards or by a lack of delegation of the actual powers needed, thus transgressing employees' norms of equitable fairness (Bryson et al. 2012, Böckerman 2011, Wood \& Bryson 2009).

When judging an exchange or the change of the conditions of an exchange, our choice of reference point may be either some ethical standard or the 'normal' procedure and conditions in a situation: the cardinal rule of fair behaviour is that one person should not achieve a gain by simply imposing an equivalent loss on another (Kahneman et al. 1986a: 731). Lack of emphasis on or deficiency in ability to convince employees on this point, or indeed employee representatives' conscious framing of a conflict in precisely such terms, may generate a sense of lack of fairness among employees and thus provoke workplace conflicts (Scheuer 2006a).

\section{Endowment Effects: Equity v. Equality}

In much of the literature, the consideration of norms is related to issues of the pay/work-effort relationship, while less has been done considering other important motivational aspects of the employment relationship, especially various issues of intrinsic motivation. While an employee may feel intrinsically motivated to undertake a specific task in the desired direction, with the desired intensity and persistence of effort, social norms in the work group may contribute to or detract from this motivation, in the same manner that extrinsic motivation may be perceived as crowding out or crowding in the motivation of the employee, according to Motivation Crowding Theory (Frey 1998, 2002, Frey \& Osterloh 2010, Latham 2012, Lawler 1990, Ryan \& Deci 2000).

Some social norms relate to ownership in the broad sense, implying 'ownership' of a job, of a particular level of salary, of particular rights and small privileges in the workplace etc., this has been labelled the endowment effect (Kahneman et al. 1990, Thaler 1980). It is thus against the sense of equity that one should lose anendowment (such as tolerate a salary reduction or an unwanted lengthening of working hours) much more than the loss of prospective gain (e.g. loss of an expected pay bonus), although even a pay reduction appears to be acceptable in certain circumstances (Kahneman et al. 1986a). This may explain why pay increases for the low-paid may be seen by others (the higher paid) as a loss of an endowment (a privilege or a sense of ownership), and be reframed as a smaller percentage increase and thus an incurredloss, cf. Elster (1989a, 2009).

Examples of this type of reasoning often occur publicly in collective bargaining in coordinated market economies (cf. Hall \& Soskice 2001), as in some European countries. In Liberal Market Economies, and indeed in local company bargaining, this type of argumentation may be less prevalent, at least in the quasi-public discourse, but the deliberations behind them may nevertheless loom large in the minds of (groups of) employees and in the group-oriented subculture, i.e. in the informal organization.

The problem, then, is this: norms of equity may thus run flat in the face of norms of equality. Status quo is not the same as equity, since equity expresses a norm of 'to each according to his $\mathrm{X}$ ', where $\mathrm{X}$ may be education, experience, position in the status hierarchy etc., and this may not be met by status quo, although strongly entrenched non-equitable practices may prevail due to the institutionalizing effects of more or less subconscious taken-for-granted modes of evaluation, i.e. through isomorphic processes (cf. Scott 1995). Equality is also different from these two, since equality may express the requirement of equal treatment in the face of differences 
in race, religion, gender, age, sexual orientation etc., but also equality as a social norm of more equal distribution of income and wealth in society, regardless of education, seniority, position etc. Equality may be local (company- or profession-based) or societal (Elster 1989a: 224-31, 1989b, Scheuer 2000). The adherence to social norms does not reduce conflict in society and it does not solve all distributional problems. Since social norms among employees will be heterogeneously distributed, a 'normative confrontation' will often occur in the workplace context, and it requires both procedures for conflict resolution and a reciprocal insight in and understanding of the social norms underlying the bargaining positions of the other part. Endowment effects are relatively resilient, as are social norms, but they have dynamic properties, depending inter alia on framing (Boudon 2001, Joas 2000).

Employees in work situations exert individual agency. The decisions that agents continuously make form the core of the issue of work motivation. Work motivation may be defined generally as the process that determines how energy is used to satisfy needs, and thus motivation is a cognitive resource allocation process in which the agent chooses the time and energy to be spent on an array of more or less work-related tasks. Motivation includes direction, intensity and persistence of the expended effort, and this process is future-oriented in that agents anticipate the amount of satisfaction that they suppose will occur when outcomes are received (Latham 2012: 193, Pritchard et al. 2002, Vroom 1964).

\section{Motivation and Incentives}

At the beginning of the $21^{\text {st }}$ century, much progress has been made in the understanding of human work motivation, even though the influence on motivation from social norms is still not well understood. Some of the concepts from classic motivation are still heavily utilized, especially Herzberg's distinction (1966) between intrinsic and extrinsic motivational factors, and the debate between (psychological) intrinsic motivation theories and (economic) extrinsic or incentive theories is still very much alive (Deci 1975, Deci \& Ryan 1985, Frey 1998, 2002, Lawler 2000, Ryan \& Deci 2000), while some have attempted to integrate the two perspectives (e.g. Steel \& König 2006). Deci's and Frey's contributions make much of the possible outcrowding effects of extrinsic incentives, especially when they are experienced as 'controlling' (Frey 1998, and also Andersen \& Serritzlew 2012). This may be an expression of an individual wish not to be controlled, or to be controlled less, but it may also have spilt over from fairness norms based on status quo which might imply that pay bonuses generally are controlling. However, some evidence points in the opposite direction, since those who report having pay-for-performance systems generally consider their company more equitable than those who do not have such an arrangement (Scheuer 2006b). This is the case even for those not obtaining a bonus, and therefore, it does not express any simple economic satisfaction with a higher salary (a simple rational choice valuation), rather it expresses satisfaction with the implicit deal underlying such an arrangement, i.e. an acceptance of the deal as normatively fair.

More recent theories have appeared under the label of 'Public Service Motivation' (Perry \& Hondgehem 2008). This theory connects the traditional motivational aspects of work with the impact of the employee's interest in serving the public good, and the effect of variations in motivational systems has been shown in various particular work contexts (Andersen \& Serritzlew 2012, Andersen et al. 2011). More generally, others have pointed out how the introduction of choice and competition among public sector institutions may enhance performance (Grand 2003, 2007, 2010, Marsden 2004b, and Thaler\& Sunstein 2008).

An important contribution to motivation theory is Latham and Locke's goal-setting theory, which moved on from equity theory and expectancy theory in establishing that (a) companies must supply employees with relatively specific and obtainable goals in their work defined (b) from the work's basic characteristics and (c) from an understanding of the goals and preferences of employees (Latham \& Locke 1979, 1991, Locke 2000, Locke \& Latham 1990, 2004, Tversky \& Kahneman 1986, Wicker et al. 1993). This theory states explicitly that feedback and recognition is not enough, it is mediated by the setting of specific goals. Further, ability to perform faced with difficult goals is mediated by the level of goals by individual employees themselves: people with high goals and high self-efficacy have higher performance yet lower expectancies of success than those with low goals and a low performance level. Furthermore, goal setting is a discrepancy-creating process, i.e. motivation requires 'feed-forward' control in addition to feedback, since employees with high self-efficacy often set themselves even higher goals, creating a novel discrepancy. Many of these processes will become influenced by employees' social norms, which may add to or detract from perceived self-efficacy and individual goal setting.

Obviously, companies need to have substantial pay variance, often also a degree of variance between peers, but they also need to be seen as fair in their pay policies by every group of employees. This is the basic dilemma of companies, and thus of payment system and for the whole HRM system. One way of managing is to keep actual 
pay levels and individual pay secret, perhaps even forbidding employees to exchange this information, but this approach is hardly ever completely successful and it also diminishes confidence levels between management and employees.

What is considered normal or ideal will vary with attributes of the employment situation or of the employee such as employment status, employment sector, employment tenure or age, level of formal education and (perhaps) gender. Added to this may be attitudinal factors such as institutional membership and political orientation. While theories of social norms and fairness constraints in general have received quite some attention, relatively little has been written concerning how social norms vary according to these variables in the employment setting. However, one should not only look at the prevalent social norms in the working populace. One must also specify how these very norms are contingent upon (a) aspects of social status, personal attributes and attitudes and (b) institutional characteristics (e.g. trade unionism, collective bargaining) of the work situation. At the same time, there is the issue of establishing exactly when an action by management turns unfair and when change programs therefore may run into trouble. May teamwork (and other dynamic forms of cooperation) become impeded by choosing a reward structure that is economically and rationally fair, but yet considered unfair for some reason?

\section{Propositions for HRM}

Below, a number of consequences of the above considerations are spelt out for HR management. These consequences concerned with the more specific aspects of payment and reward structures, and their theoretical and analytical underpinnings.

- Under contingent pay, systems that entail a degree of choice are perceived as fair, and ensures perceived fairness of outcomes (even when the individual misses the incentive), while systems that entail increased perceived control are less so. This impinges strongly on employee motivation and effort (Allgulin \& Ellingsen 2002, Andersen \& Pallesen 2008, Frey 1998, 2002, Frey \& Osterloh 2010, Sewell \& Barker 2006).

- Contingent pay systems (ever so economically marginal) enhance management's insights into the individual employee's contribution. However, insights should be perceived as non-controlling, i.e. enabling some choice.

- Under contingent pay systems, social norms based on equity will vary positively with employment status, level of formal education, membership of trade unions or associations, high-status unions having the strongest support.

- Under contingent pay systems, framing may impinge on actors' activation of their respective social norms of equity and equality, respectively, enabling greater or lesser envy towards the differentiation of rewards.

- Under teamwork, pay differences among participants matter little, but contingent team rewards may hinder cooperation (contribution) by some participants, depending on the size of the relative differentials, depending on (1) framing and (2) size of relative differences. Specifically, very small or very large variations in contingent team reward are particularly impeding (U-shaped) (Auriol et al. 2002, Arrowsmith \& Marginson 2010, Barker 1993, 1999).

- In temporary teamwork (e.g. Task Forces), how can contingent teamwork reward be implemented and framed to avoid envy? Either, one may mete it out percentage-wise or one may have to move parts of the rewards for higher-earners to other for a.

- In permanent teamwork (e.g. standing committees or quality circles), how can envy be minimized? This can be done by changing the framing, e.g. by making contingent rewards less relative to basic pay (i.e. more egalitarian), or by moving rewards for the higher-earners out of the teamwork.

- Local (i.e. collegial) perceived fairness of relative pay distribution increases with principal's insight in individual performance and with members' perception of principal's fairness in t-1 (Prendergast 2002, Rotemberg 2002). This also increases the perceived fairness of own pay. Perceived fairness also increases when a collective bargaining procedure is in place, while the perceived fairness of own pay does not (Sisson \& Marginson 2002).

- Collective bargaining agreements enhance fairness perceptions both in times of slack and when times are good, and thus enable rationalization processes and contingent pay increases or reductions. It does, however, probably require more 'linearity', i.e. stricter egalitarianism in increases and reductions than management might otherwise prefer.

- It is considered as unfair to reduce nominal pay due to excess labour supply or even under low company profits, and it can only be perceived as fair under impending company losses (Elster 1989, 2009, Kahneman et al. 1986a, 1990). 
- Firms that operate with bonus systems or profit sharing encounter less resistance in reducing overall pay during slack (Kahneman et al. 1986a: 740). Firms that have collective bargaining procedures in place can also more easily reduce nominal pay without becoming perceived as unfair (Ingram 1991, Traxler et al. 2007).

\section{Conclusion}

In the debate for and against the utilization of incentives in the employment relationship, there is often very strong polarization. You are either for it or against it. However, theories turning their back entirely on economic incentives when it comes to motivation seem to ignore that any wage structure, even complete egalitarianism, contains a kind of incentive. Maybe not a kind, however, that you would think furthered the productive and concerted efforts of employees. Therefore, one may underscore that there are many options in the introduction or the rearrangement of a performance and reward management system, especially concerning

- The formalization of the criteria for bonuses and rewards

- The share of the reward package allocated to variable pay

- The degree of 'publicity' connected to the contingent rewards

In other words, contingent economic rewards may be 'high-powered' or 'low-powered' (Langbein 2010: 15-6). In situations where there are reasons to believe that the divisive nature of contingent individual rewards is detrimental to collective performance, or where high-powered incentives may be perceived as controlling and thus crowd out intrinsic motivation or task motivation, it may be wiser to go for the low-powered contingent reward system. This will enable management to reward good individual performance while simultaneously keeping intrinsic (task) motivation and (not in the least) avoiding the divisive effects on collaborative efforts. Most companies are, after all, collaborative efforts!

\section{References}

Abell, P. (1995). The new institutionalism and rational choice theory. In Scott, W. R., \& Christensen, S. (Eds.), The Institutional Construction of Organizations. London: Sage Publications.

Allgulin, M., \& Ellingsen, T. (2002). Monitoring and Pay. Journal of Labor Economics, 20(2, 1), 201-16. http://dx.doi.org/10.1086\%2F338214

Andersen, L. B., \& Pallesen, T. (2008). "Not Just for the Money?" How Financial Incentives Affect the Number of Publications at Danish Research Institutions. International Public Management Journal, 11(1), 28-47. http://dx.doi.org/10.1080/10967490801887889

Andersen, L. B., \& Serritzlew, S. (2012). Does public service motivation affect the behavior of professionals? $\begin{array}{llll}\text { International Journal of Public Administration, } & 35(1), & 19-29 .\end{array}$ http://dx.doi.org/10.1080/01900692.2011.635277

Andersen, L. B., Pallesen, T., \&Pedersen, L. H. (2011). Does ownership matter? Public service motivation among physiotherapists in the private and public sectors in Denmark. Review of Public Personnel Administration, 31(1), 10-27. http://dx.doi.org/10.1177/0734371X10394402

Arrowsmith, J., \& Marginson, P. (2010). The decline of incentive pay in British manufacturing. Industrial Relations Journal, 41(4), 289-311. http://dx.doi.org/10.1111/j.1468-2338.2010.00570.x

Auriol, E., Friebel, G., \& Pechlivanos, L. (2002). Career Concerns in Teams. Journal of Labor Economics, 20(1, 1), 289-307.

Axelrod, R. (1984). The Evolution of Cooperation. New York: Basic Books.

Barker, J. R. (1993). Tightening the Iron Cage: Concertive Control in Self-Managing Teams. Administrative Science Quarterly, 38(3), 408-37. http://dx.doi.org/10.2307/2393374

Barker, J. R. (1999). The Discipline of Teamwork.Participation and Concertive Control. Thousand Oaks: Sage.

Böckerman, P., Bryson, A., \& Ilmakunnas, P. (2011). Does high involvement management improve worker wellbeing? CEP Discussion Paper, The Centre for Economic Performance, London School of Economics, No. 1095. http://dx.doi.org/10.1016\%2Fj.jebo.2012.09.005

Boudon, R. (2001). The Origin of Values: Essays in the Sociology and Philosophy of Beliefs. New Brunswick: Transaction.

Bryson, A., Dale-Olsen, H., \& Barth, E. (2012). Do higher wages come at a price? Journal of Economic Psychology, 33(1). 251-63. http://dx.doi.org/10.1016/j.joep.2011.10.005 
Deci, E. L. (1975). Intrinsic Motivation. New York, NY: Plenum. http://dx.doi.org/10.1007/978-1-4613-4446-9

Deci, E. L., \& Ryan, R. M. (1985). Intrinsic Motivation and Self-Determination in Human Behavior. New York, NY: Plenum.

Elster, J. (1989a). The Cement of Society.A Study of Social Order. Cambridge: Cambridge University Press. http://dx.doi.org/10.1017/CBO9780511624995

Elster, J. (1989b). Social norms and economic theory. Journal of Economic Perspectives, 3(4), 99-117. http://dx.doi.org/10.1257/jep.3.4.99

Elster, J. (2007). Explaining Social Behavior. Cambridge: Cambridge University Press. http://dx.doi.org/10.1017\%2FCBO9780511806421

Elster, J. (2009). Norms. In P. Hedström \& P. Bearman (Eds.), The Oxford Handbook of Analytical Sociology (pp. 195-218). Oxford: Oxford UP. http://dx.doi.org/10.1111/j.1468-4446.2012.01425_2.x

Fehr, E., Goette, L., \& Zehnder, C. (2009). A behavioral account of the labor market: the role of fairness $\begin{array}{lllll}\text { concerns. Annual } & \text { Review }\end{array}$ http://dx.doi.org/10.1146/annurev.economics.050708.143217

Frey, B. S. (1998). Not just for the Money. Economic Theory of Personal Motivation. Cheltenham: Edward Elgar.

Frey, B. S. (2002). Inspiring Economics: Human Motivation in the Political Economy. Cheltenham: Edward Elgar.

Frey, B. S., \& Osterloh, M. (2010). Successful Management by Motivation: Balancing Intrinsic and Extrinsic Incentives. Berlin: Springer.

Grand, J. L. (2003). Motivation, Agency and Public Policy. Of Knights and Knaves, Pawns and Queens. Oxford: Oxford UP. http://dx.doi.org/10.1093/0199266999.001.0001

Grand, J. L. (2007). The Other Invisible Hand.Delivering Public Services through Choice and Competition. Oxford: Princeton UP.

Grand, J. L. (2010). Knights and Knaves Return: Public Service Motivation and the Delivery of Public Services. International Public Management Journal, 13(1), 56-71. http://dx.doi.org/10.1080/10967490903547290

Hall, P. A., \& Soskice, D. (2001). Varieties of Capitalism.The Institutional Advantage of Competitive Advantage. Oxford: Oxford University Press. http://dx.doi.org/10.1093/0199247757.001.0001

Hechter, M. (1987). Principles of Group Solidarity. Berkeley: University of California Press.

Herzberg, F. (1966). Work and the Nature of Man. New York: The World Publishing Company.

Ingram, P. (1999). Changes in Working Practices in British Manufacturing Industry in the 1980s: A Study of Employee Concessions Made During Wage Negotiations. British Journal of Industrial Relations, 29(1), 1-13. http://dx.doi.org/10.1111/j.1467-8543.1991.tb00224.x

Joas, H. (2000). The Genesis of Values. Cambridge: Polity.

Kahneman, D. (2011). Thinking, Fast and Slow. London: Allen Lane/Penguin.

Kahneman, D., Knetsch, J. L., \& Thaler, R. (1986a). Fairness as a constraint on profit seeking: Entitlements in the market. American Economic Review, 76(4), 728-41.

Kahneman, D., Knetsch, J. L., \& Thaler, R. (1986b). Fairness and the assumptions of economics. Journal of Business, 59(4), S285-S300. http://dx.doi.org/10.1086\%2F296367

Kahneman, D., Knetsch, J. L., \&Thaler, R. (1990). Experimental tests of the endowment effect and the Coase theorem. Journal of Political Economy, 98(6), 1325-48. http://dx.doi.org/10.1086/261737

Langbein, L. (2010). Economics, public service motivation and pay for performance: complements or substitutes? International Public Management Journal, 13(1), 9-23. http://dx.doi.org/10.1080/10967490903547134

Latham, G. P. (2012). Work Motivation. History, Theory, Research, and Practice (2nd ed.). London: Sage.

Latham, G. P., \& Locke, E. A. (1979). Goal setting: a motivational technique that works. Organizational Dynamics, 8(2), 68-80. http://dx.doi.org/10.1016/0090-2616(79)90032-9

Latham, G. P., \& Locke, E. A. (1991). Self-regulation through goal setting.Organizational Behavior and Human Decision Processes, 50(2), 212-47. http://dx.doi.org/10.1016/0749-5978(91)90021-K 
Lawler, E. E. (1990). Strategic Pay: Aligning Organizational Strategies and Pay Systems. San Francisco: Jossey-Bass.

Lawler, E. E. (2000). Rewarding Excellence. Pay Strategies for the New Economy. San Francisco: Jossey Bass.

Locke, E. A. (2000). Motivation, cognition, and action: An analysis of studies of task goals and knowledge. $\begin{array}{lllll}\text { Applied Psychology. An } & \text { International }\end{array}$ http://dx.doi.org/10.1111\%2F1464-0597.00023

Locke, E. A., \& Latham, G. P. (1990). A theory of goal setting and task performance. Englewood Cliffs, NJ: Prentice-Hall.

Locke, E. A., \& Latham, G. P. (2004). What should we do about motivation theory? Six recommendations for the $21^{\text {st }}$ century. Academy of Management Review, 29(3), $379-87$. http://dx.doi.org/10.5465/AMR.2004.13670974

Marsden, D. (2004a). The 'Network Economy' and Models of the Employment Contract. British Journal of Industrial Relations, 42(4), 659-84. http://dx.doi.org/10.1111/j.1467-8543.2004.00335.x

Marsden, D. (2004b). The role of performance-related pay in renegotiating the "effort bargain" the case of the British public service. Industrial \& Labor Relations Review, 57(3), 350-370. http://dx.doi.org/10.2307/4126656

Perry, J. L., \& Hondgehem, A. (2008). Motivation in Public Management. The Call of Public Service. Oxford: Oxford UP.

Prendergast, C. (2002). Uncertainty and Incentives. Journal of Labor Economics, 20(2, 2), S115-37. http://dx.doi.org/10.1086\%2F338676

Pritchard, R. D., Paquin, A. R., DeCuir, A. D., McGormick, M. J., \& Bly, P. R. (2002). The measurement and improvement of organizational productivity. In Pritchard, R. D., Holling, H., Lammers, F., \& Clark, B. D. (Eds.), Improving Organizational Performance with the Productivity Measurement and Enhancement System (pp. 3-49). Huntington, NY: Nova Science.

Rotemberg, J. J. (2002). Perceptions of Equity and the Distribution of Income. Journal of Labor Economics, 20(2, 1), 249-88. http://dx.doi.org/10.1086\%2F338218

Rousseau, D. M. (1995). Psychological Contracts in Organizations: Understanding Written and Unwritten Agreements. London: Sage.

Ryan, R. M., \& Deci, E. L. (2000). Intrinsic and extrinsic motivations: classic definitions and new directions. Contemporary Educational Psychology, 25(1), 54-67. http://dx.doi.org/10.1006/ceps.1999.1020

Scheuer, S. (2000). Social and Economic Motivation at Work: Theories of Work Motivation Reassessed. Copenhagen: CBS Press.

Scheuer, S. (2006a). A Novel Calculus? Institutional Change, Globalization and Industrial Conflict in Europe. European Journal of Industrial Relations, 12(2), 143-65. http://dx.doi.org/10.1177/0959680106065032

Scheuer, S. (2006b). Årsbonus som incitamentløn: Større indsats eller mere splittelse? Ledelse og erhvervsøkonomi, 70(2), 100-111.

Schuster, J. R., \& Zingheim, P. K. (1992). The New Pay: Linking Employee and Organizational Performance. New York: Lexington Books.

Scott, W. R. (1995). Institutions and Organizations. London: Sage.

Sewell, G., \& Barker, J. R. (2006). Coercion versus Care: Using Irony to Make Sense of Organizational Surveillance. Academy of Management Review, 31(4), 934-61. http://dx.doi.org/10.5465/AMR.2006.22527466

Sisson, K., \& Marginson, P. (2002). Co-ordinated Bargaining: A Process for Our Times? British Journal of Industrial Relations, 40(2), 197-220. http://dx.doi.org/10.1111/1467-8543.00229

Steel, P., \& König, C. J. (2006). Integrating theories of motivation. Academy of Management Review, 31(4), 889-913. http://dx.doi.org/10.5465/AMR.2006.22527462

Thaler, R. (1980). Towards a positive theory of consumer choice. Journal of Economic Behavior and Organization, 1(1), 39-60. http://dx.doi.org/10.1016/0167-2681(80)90051-7 
Thaler, R. H., \&Sunstein, C. R. (2008). Nudge. Improving Decisions About Health, Wealth, and Happiness. New York: Penguin.

Traxler, F., Brandl, B., \& Glassner, V. (2007). Pattern Bargaining: An Investigation into its Agency, Context and Evidence. British Journal of Industrial Relations, $46(1), \quad 33-58$. http://dx.doi.org/10.1111/j.1467-8543.2007.00664.x

Tversky, A., \& Kahneman, D. (1986). Rational choice and the framing of decisions. Journal of Business, 59(4), S251-S278. http://dx.doi.org/10.1086/296365

Vroom, V. H. (1964). Work and Motivation. New York, NY: John Wiley \& Sons.

Wicker, F. W., Brown, G., Wiehe, J., Hagen, A. S., \& Reed, J. L. (1993). On reconsidering Maslow: An examination of the deprivation/domination proposition. Journal of Research in Personality, 27(2), 118-99. http://dx.doi.org/10.1006/jrpe.1993.1008

Wood, S., \& Bryson, A. (2009). High involvement management. In Brown, W., Bryson, A., Forth, J., \& Whitfield, K. (Eds.), The Evolution of the Modern Workplace (pp. 151-76). Cambridge: Cambridge UP.

\section{Copyrights}

Copyright for this article is retained by the author(s), with first publication rights granted to the journal.

This is an open-access article distributed under the terms and conditions of the Creative Commons Attribution license (http://creativecommons.org/licenses/by/3.0/). 